Additional services for Geological Magazine:

Email alerts: $\underline{\text { Click here }}$

Subscriptions: $\underline{\text { Click here }}$

Commercial reprints: $\underline{\text { Click here }}$

Terms of use : $\underline{\text { Click here }}$

\title{
Chrono- and lithostratigraphy of a Mesozoic-Tertiary fore- to intra-arc basin: Adelaide Island, Antarctic Peninsula
}

TEAL R. RILEY, MICHAEL J. FLOWERDEW and MARTIN J. WHITEHOUSE

Geological Magazine / Volume 149 / Issue 05 / September 2012, pp 768 - 782

DOI: 10.1017/S0016756811001002, Published online: 30 November 2011

Link to this article: http://journals.cambridge.org/abstract S0016756811001002

How to cite this article:

TEAL R. RILEY, MICHAEL J. FLOWERDEW and MARTIN J. WHITEHOUSE (2012). Chrono- and lithostratigraphy of a Mesozoic-Tertiary fore- to intra-arc basin: Adelaide Island, Antarctic Peninsula. Geological Magazine,149, pp 768-782 doi:10.1017/S0016756811001002

Request Permissions : $\underline{\text { Click here }}$ 


\title{
Chrono- and lithostratigraphy of a Mesozoic-Tertiary fore- to intra-arc basin: Adelaide Island, Antarctic Peninsula
}

\author{
TEAL R. RILEY* $\dagger$, MICHAEL J. FLOWERDEW* \& MARTIN J. WHITEHOUSE \\ *British Antarctic Survey, Natural Environment Research Council, Madingley Road, Cambridge, CB3 0ET, UK \\ $\ddagger$ Swedish Museum of Natural History, Box 50007, Stockholm 104 05, Sweden
}

(Received 9 February 2011; accepted 25 October 2011; first published online 30 November 2011)

\begin{abstract}
The Mesozoic fore-arc of the Antarctic Peninsula is exposed along its west coast. On Adelaide Island, a 2-3 km succession of turbiditic coarse sandstones and volcanic rocks is exposed. Four U- $\mathrm{Pb}$ (zircon) ages are presented here that, in combination with a new stratigraphy, have permitted a robust chrono- and lithostratigraphy to be constructed, which in turn has allowed tentative correlations to be made with the Fossil Bluff Group of Alexander Island, where the 'type' fore-arc sequences are described. The lithostratigraphy of Adelaide Island includes the definition of five volcanic/sedimentary formations. The oldest formation is the Buchia Buttress Formation (149.5 $\pm 1.6 \mathrm{Ma})$ and is correlated with the Himalia Ridge Formation of Alexander Island. The sandstone-conglomerate dominated succession of the Milestone Bluff Formation (113.9 $\pm 1.2 \mathrm{Ma}$ ) is tentatively correlated with the Pluto Glacier Formation of Alexander Island. Three dominantly volcanic formations are recognized on Adelaide Island, akin to the volcanic rocks of the Alexander Island Volcanic Group; the Mount Liotard Formation is formed of $2 \mathrm{~km}$ of basaltic andesite lavas, whilst the Bond Nunatak Formation is also dominated by basaltic andesite lavas, but interbedded with volcaniclastic rocks. The Reptile Ridge Formation has been dated at $67.6 \pm 0.7 \mathrm{Ma}$ and is characterized by hydrothermally altered rhyolitic crystal-lithic tuffs. Tentative correlations between Adelaide Island and Alexander Island preclude the two areas forming part of distinct terranes as has been suggested previously, and a proximal source for volcaniclastic sediments also indicates an exotic terrane origin is unlikely.
\end{abstract}

Keywords: fore-arc, Gondwana, subduction, chronostratigraphy, Antarctica, Jurassic, Cretaceous.

\section{Introduction}

During the Mesozoic, Adelaide Island was situated on the western edge of the continental margin arc of Gondwana in a probable fore- or intra-arc position (Griffiths \& Oglethorpe, 1998). The area forms part of the geophysically and geologically defined Western Zone of the Central Domain of the Antarctic Peninsula (Fig. 1), a Mesozoic magmatic arc terrane that formed in response to subduction along the protoPacific margin of Gondwana (Vaughan \& Storey, 2000; Ferraccioli et al. 2006).

The fore-arc sequences (Fossil Bluff Group) of Alexander Island to the south of Adelaide Island have been well documented (e.g. Butterworth et al. 1988) and were considered by Vaughan \& Storey (2000) to form a distinct tectonic unit (the Western Domain; Fig. 1) to that of the Central Domain. The correlation of volcano-sedimentary sequences across these two parts of the Mesozoic fore-arc will be used to verify the accuracy of terrane boundaries and the timing of accretion of the Antarctic Peninsula.

$\mathrm{U}-\mathrm{Pb}$ (zircon) age data reported here, in conjunction with re-interpreted ${ }^{40} \mathrm{Ar}-{ }^{39} \mathrm{Ar}$ data and a complete revision of the lithostratigraphy has enabled a robust chronostratigraphy of Adelaide Island to be constructed. Adelaide Island sits in a geologically important position across the fore- to intra-arc sector

$\dagger$ †uthor for correspondence: t.riley@bas.ac.uk of the Antarctic Peninsula, and correlations between its successions and those of Alexander Island and the Antarctic Peninsula should provide a test of terrane boundary models, timing of accretion and probability of the Western Domain being exotic (Vaughan \& Storey, 2000).

\section{Lithostratigraphy of Adelaide Island}

Adelaide Island is situated off the west coast of the Antarctic Peninsula, to the north of Alexander Island (Fig. 1). Adelaide Island can be divided into two distinct topographic areas: the Fuchs Ice Piedmont to the west and a mountainous area on the eastern part of the Island, including the massifs of Mount Liotard, Gaudry and Bouvier (Fig. 2).

Adelaide Island preserves a 2-3 km thick succession of sedimentary, volcaniclastic and volcanic rocks, which are interpreted to be late Mesozoic in age and represent sedimentation and volcanism in a fore- to intra-arc position. Later plutonism is exposed across the Island and probably forms part of the Antarctic Peninsula batholith (Leat, Scarrow \& Millar, 1995).

The geology of Adelaide Island was first described in detail by G. J. Dewar (unpub. Ph.D. thesis, Univ. Birmingham, 1965; 1970) and later by Griffiths \& Oglethorpe (1998) who were not able to place too much chronological control on the stratigraphy they proposed, but they did assign a probable Late Jurassic 


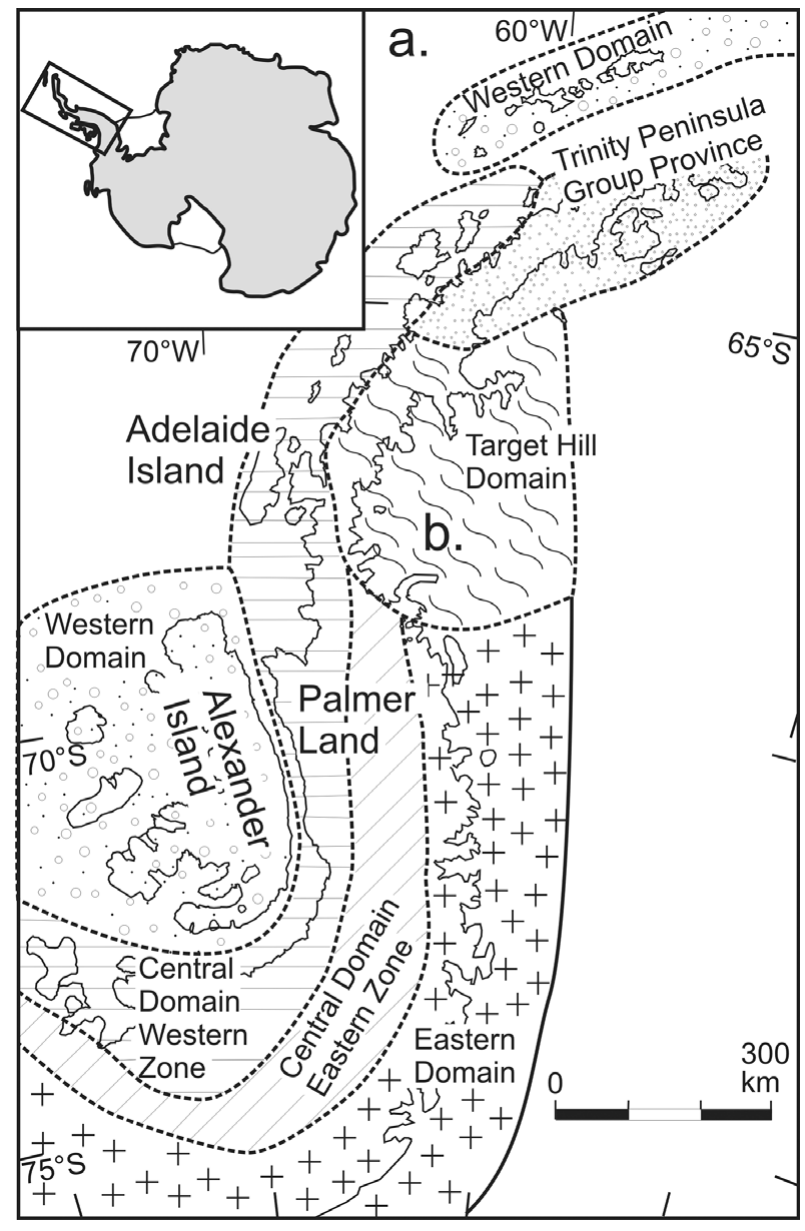

Figure 1. Terrane map for the Antarctic Peninsula after Vaughan \& Storey (2000) and Ferraccioli et al. (2006).

age to the stratified rocks of Adelaide Island based on similarities to rocks from elsewhere on the west coast of the Antarctic Peninsula.

A revised stratigraphy of Adelaide Island is proposed here, based on recent geological mapping and the previous field studies of C. J. Griffiths (e.g. Griffiths \& Oglethorpe, 1998) and G. J. Dewar (e.g. Dewar, 1970) and spectral mapping (Haselwimmer, Riley \& Liu, 2010). The new formations proposed here are supported by newly acquired geochronology.

\section{2.a. Buchia Buttress Formation}

The Buchia Buttress Formation crops out at its type locality of Buchia Buttress and extends south to the Shambles Glacier region, along the Sheldon Glacier region, with minor outcrop on the western side of Leonie Island (Fig. 2). The extent of the Buchia Buttress Formation to the north of Buchia Buttress is less certain given the paucity of outcrop, but it has been tentatively extrapolated to the north and west of Bond Nunatak (Fig. 2) based on aeromagnetic data (British Antarctic Survey, unpub. data).

At Buchia Buttress, the succession is characterized by volcanic breccias, silicic crystal tuffs, immature volcaniclastic rocks and coarse-grained volcaniclastic sandstone units with interbedded cobble/boulder conglomerates. An alternating fining-upwards sequence is observed at Buchia Buttress consisting of sandstones, interbedded with pebble/boulder conglomerates, crossbedded medium-fine-grained sandstones and ripple cross-laminated sandstones. Within this sequence, cherty silicic crystal tuffs occur, which are interpreted to have been emplaced into water. The tuffs are greengrey in colour, medium-fine grained and include rare lithic fragments and oblate, porphyritic pumice. The sandstone beds are locally fossiliferous, particularly at Buchia Buttress where marine invertebrates are common, including bivalves (Buchia sp., Inoceramus sp.), perisphinctid ammonites and belemnites (Hibolithes sp.). Thomson (1972) favoured a KimmeridgianTithonian age (likely Early Tithonian) based on the comparison of the fauna to elsewhere on the Antarctic Peninsula.

The succession at Buchia Buttress and southern Mount Bouvier is estimated at $830 \mathrm{~m}$ in thickness. Elsewhere, the succession is not as complete and the exposures south of the Shambles Glacier are characterized by sandstone and conglomerate units, with far less abundant volcanic material.

The lower part of the succession, to the south of Mount Bouvier, is intruded by tonalite of the Mount Bouvier intrusive suite.

\section{2.b. Milestone Bluff Formation}

The thick (at least $1.5 \mathrm{~km}$ ) sequence of sedimentary, volcaniclastic and volcanic lithologies dominate the geology of the central escarpment of Adelaide Island. The sequences exposed from Fletcher Bluff, Milestone Bluff and south towards Window Buttress can all be correlated with a high degree of confidence, although the exposures at the southern end of the range at Cape Alexandra are deformed and have a greater volcanic component and are only tentatively assigned to the Milestone Bluff Formation.

The sequences at Fletcher Bluff, Milestone Bluff and Window Buttress are dominated by sandy turbiditic sediments with subordinate ash flow-, crystal- and vitric tuffs. Rare ignimbrite beds are also present with strongly flattened (6:1) pumices (Fig. 3a). The ignimbrites are typically feldspar porphyritic and together with crystal tuffs can form beds up to $30 \mathrm{~m}$ in thickness. Cobble and boulder conglomerates are prominent horizons throughout the succession (Fig. $3 \mathrm{~b}$ ), with individual beds up to greater than $20 \mathrm{~m}$ in thickness. The conglomerates are typically poorly sorted, dominantly clast-supported, with individual clasts up to $0.8 \mathrm{~m}$ in diameter and are the result of deposition from high density turbidity currents or debris flows in an alluvial fan environment.

The sequences dip shallowly $\left(\sim 10-15^{\circ}\right)$ to the east $\left(85-105^{\circ}\right)$ and are offset by numerous, minor, reverse faults. The conglomerate clast orientations indicate a general source direction from the east to the southeast (Griffiths \& Oglethorpe, 1998; this study), which is 


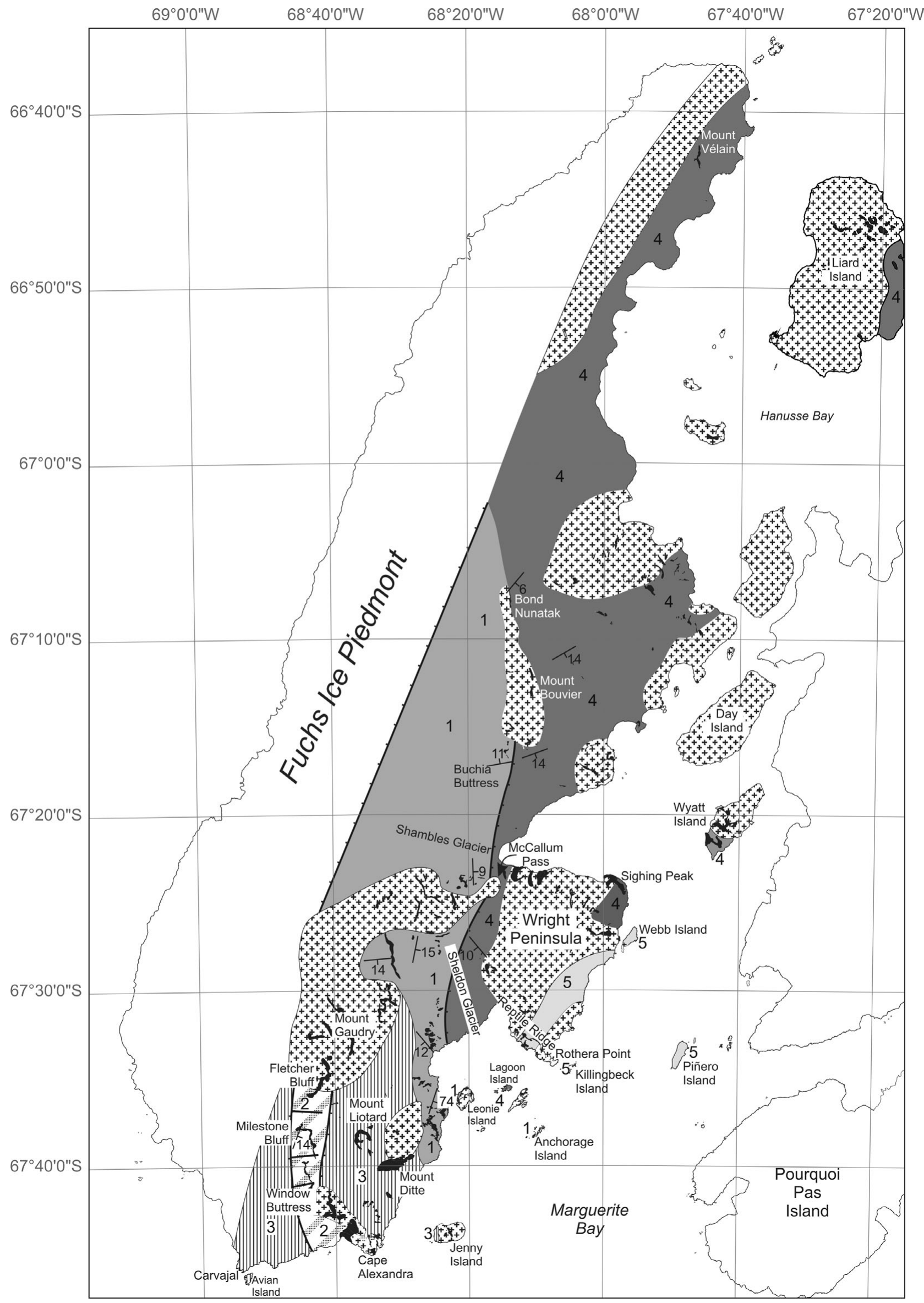

Figure 2. Revised geological map of Adelaide Island. 


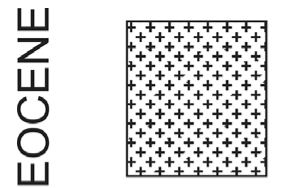

Adelaide Island Intrusive Suite

Typically granodiorite-gabbro hybrid plutons which crop out widely on the Wright Peninsula. Increasingly silicic further north, where quartz monzonite and tonalite more abundant. An emplacement age of 45 - $52 \mathrm{Ma}$ (this study; Griffiths \& Oglethorpe, 1998). Associated with dolerite dyke intrusion.

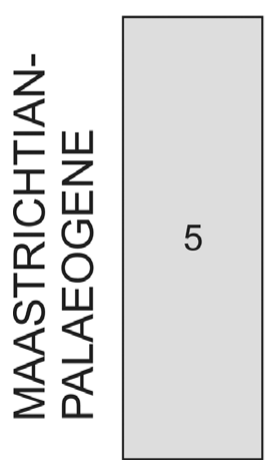

Reptile Ridge Formation

Rhyolitic ignimbrites, crystal- and crystal lithic-tuffs up to $400 \mathrm{~m}$ in thickness. Outcrop extent is restricted to Reptile Ridge, Webb Island, Killingbeck Island and Piñero Island. Eruption age of $67.6+0.7 \mathrm{Ma}$ (this study).

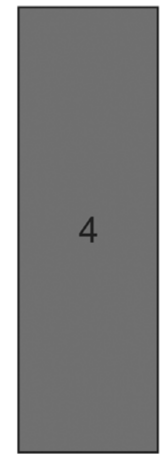

Bond Nunatak Formation Basaltic volcanic breccias, aphanitic basaltic andesite lavas and basaltic pillow lavas (at Sighing Peak). Interbedded with coarsegrained, juvenile sandstones and cobble/boulder conglomerates. Crop out through central Adelaide Island from Mount Vélain to Bond Nunatak and Lagoon Island. Probable age of $\sim 70$ Ma.

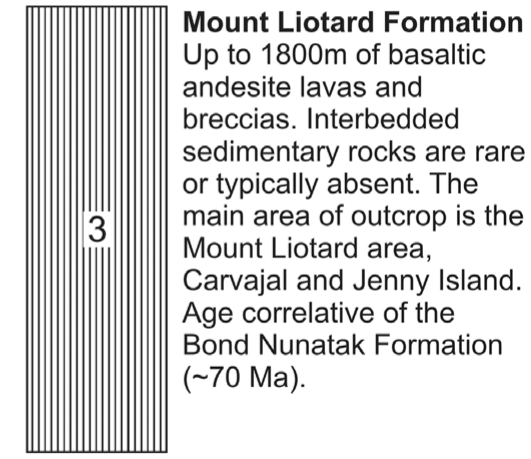

Mount Liotard Formation andesite lavas and breccias. Interbedded sedimentary rocks are rare or typically absent. The is the Mount Liotard area, ajal and Jenny Island. correlative of the Bond Nunatak Formation $(\sim 70 \mathrm{Ma})$

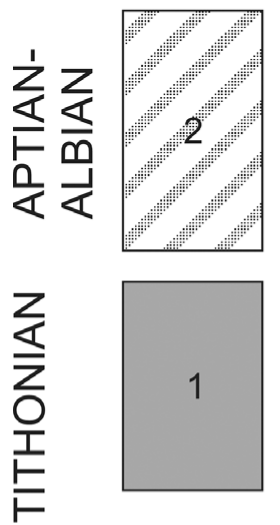

\section{Milestone Bluff Formation}

Bedded sedimentary, volcaniclastic and volcanic rocks exposed in the escarpments of south, central Adelaide Island at Fletcher Bluff, Milestone Bluff and Window Buttress to Cape Alexandra. Dominated by cobble/boulder conglomerates and sandstones composed of juvenile volcanic material. Interbedded with rare crystal, crystal-lithic and vitric tuffs. Belemnite, bivalve and plant fossil fragments have been located at Milestone Bluff and Window Buttress. An interbedded silicic tuff has yielded an age of $113.9+1.2 \mathrm{Ma}$ (this study).

\section{GEOLOGICAL SYMBOLS}

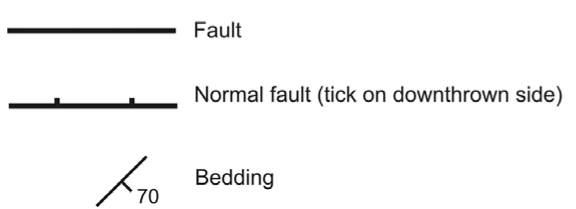

Figure 2. (Continued) Legend for geological map of Adelaide Island.

consistent with the possible source of the plutonic clasts (NW Palmer Land; Fig. 1), which have been dated at $\sim 140 \mathrm{Ma}$ (Griffiths \& Oglethorpe, 1998).

Belemnite, bivalve and plant fossil fragments have all been identified (Thomson \& Griffiths, 1994; Griffiths \& Oglethorpe, 1998; this study) from the loose debris of Milestone Bluff and Window Buttress and indicate that at least part of the succession was deposited in a shallow marine environment. The fossil fragments have tentatively been assigned a Late Jurassic age based on similarities to elsewhere on Adelaide Island and the Antarctic Peninsula (Thomson \& Griffiths, 1994).

\section{2.c. Mount Liotard Formation}

The Mount Liotard Formation is restricted to parts of southern Adelaide Island, principally the area around Mount Liotard and Mount Ditte, west to Avian Island and east to Jenny Island (Fig. 2).
Mount Liotard $(2225 \mathrm{~m})$ and the surrounding area are composed of at least $1800 \mathrm{~m}$ of basaltic andesite and andesite multiple lava flows. Individual, complete lava units are difficult to distinguish, but where possible, individual lavas of $30-40 \mathrm{~m}$ thickness have been identified within the succession. The units are typically feldspar porphyritic and are cut by rare basaltic sills. Erosional surfaces were not observed, but many flows are seen to have rubbly flow tops and intercalated autoclastic lava breccias and rare hyaloclastite beds.

A section close to the summit of Mount Liotard preserves well-exposed sequences $\sim 80 \mathrm{~m}$ thick of andesite lavas and monomict breccias.

\section{2.d. Bond Nunatak Formation}

The Bond Nunatak Formation is exposed across parts of northern and eastern Adelaide Island and possibly extending to Liard Island and Wyatt Island (Fig. 2). At Bond Nunatak, the succession is composed of thickly 
bedded sandstones and cobble/boulder conglomerates overlying andesite lavas and coarse breccias. The sequence is shallowly dipping $\left(\sim 15^{\circ}\right)$ to the southeast.

The volcanic part of the succession at Bond Nunatak is at least $400 \mathrm{~m}$ thick, with multiple porphyritic andesitic lava flows interbedded with breccias and immature volcaniclastic rocks. A continuation of this succession is observed at Mount Vélain in the northern part of Adelaide Island. At Mount Vélain, steeply dipping ( $35^{\circ}$ to the northeast) basaltic andesite breccias and aphanitic andesitic lavas are exposed. They have a total thickness of at least $300 \mathrm{~m}$ and the lavas/breccias are interbedded with minor (typically $<2 \mathrm{~m}$ thickness) units of coarse-grained immature volcaniclastic sediments.

At Bond Nunatak, the succession is intruded near its base by tonalite and gabbro, but no plutonic rocks are observed at Mount Vélain.

The basic-intermediate rocks identified on Lagoon Island (Fig. 2) are also associated with the succession observed at Bond Nunatak and Mount Vélain. Lagoon Island rocks are typically massive, finegrained-aphanitic andesite lavas, which are typically feldspar porphyritic. Breccias and autoclastic breccias are associated with the lavas, along with thinner volcaniclastic units.

Further outcrops of the Bond Nunatak Formation are observed at Sighing Peak and outcrops to the east of McCallum Pass (Fig. 2). At Sighing Peak, a total thickness of at least $600 \mathrm{~m}$ is observed. The basal part of the succession, which crops out at sea level, is a coarse volcanic breccia; the clasts are angular and include glassy shards and spatter material. The basal breccia is $\sim 200 \mathrm{~m}$ in thickness and is overlain by a more massive andesite unit, characterized by feldspar porphyritic lavas with multiple flows identified. In part, the andesite flows preserve columnar jointing (Fig. 3c).

The geographical extent of the Bond Nunatak Formation mapped with a degree of uncertainty is shown in Figure 2.

\section{2.e. Reptile Ridge Formation}

The geology of Reptile Ridge is distinct to that seen elsewhere on central and western Adelaide Island. The central and western parts of Reptile Ridge (Fig. 2) are characterized by poorly bedded rhyolite-rhyodacite crystal tuffs, lithic tuffs, ignimbrites and rare lava flows. In many places the silicic tuffs have been subject to intense hydrothermal alteration, which has led to extensive haematite mineralization.

At least $250 \mathrm{~m}$ thickness of crystal tuffs and lithic tuffs is exposed on Reptile Ridge. The volcanic rocks are interpreted as subaerial and include columnar jointed ignimbrites and crystal tuffs. The ignimbrite and crystal tuff units are typically phenocryst poor, but with a mineral assemblage characterized by embayed quartz, K-feldspar, plagioclase, biotite, magnetite, apatite, titanite, rutile and zircon.
Similar facies are exposed on Webb Island and Killingbeck Island (Fig. 2). On Webb Island, a succession of almost $300 \mathrm{~m}$ is exposed of flow-banded rhyolite lavas, crystal tuffs, ignimbrites and near vent breccias. At Killingbeck Island, $\sim 70 \mathrm{~m}$ thickness of lithic-rich crystal tuffs and agglomerate crop out, which are characterized by extensive Fe-mineralization. The tuffs are lithic-rich (>20\%) and are very friable. At the base of the exposed succession are bedded volcaniclastic sediments, which are also observed on Reptile Ridge.

\section{2.f. Adelaide Island Intrusive Suite}

A large part of the exposed geology on Adelaide Island consists of plutonic rocks of the Adelaide Island Intrusive Suite. The geology of the Wright Peninsula, Mount Bouvier and the area around Mount Gaudry is dominated by granodiorites, tonalities and gabbroic rocks. Many of the plutons are heterogeneous and are characterized by concentrations of well-rounded xenoliths, which are typically more mafic than the host (Fig. 3d). Dioritic/andesitic, feldspar-phyric xenoliths are common, and can account for $30-40 \%$ of the rock. Where hybrid plutons are observed, tonalite and/or quartz monzonite intrude the gabbro/dioritic phase. At several localities the plutonic rocks are observed to intrude the sedimentary and volcanic successions, and it has been assumed that the intrusive suite post-dates the volcaniclastic/volcanic successions (Dewar, 1970).

Granodiorite and hybrid gabbro/granodiorite plutons are the most abundant on Adelaide Island. The granodiorite is leucocratic and is dominated by plagioclase $(\sim$ 50-60\%), which often weathers orange/brown, quartz typically accounts for $\sim 10 \%$ of the rock and Kfeldspar $\sim 5 \%$. Mafic minerals are common (25\%), with green/brown amphibole abundant, along with minor amounts of biotite and epidote.

The entire volcaniclastic/volcanic stratigraphy and the plutonic rocks of Adelaide Island are cut by dolerite and intermediate-felsic composition dykes. The dykes are typically $<1 \mathrm{~m}$ thick, dip steeply ( $>75^{\circ}$ to the southeast) and strike in the range $210-230^{\circ}$ (Fig. 4), with rare dykes host to ultramafic xenoliths (Dewar, 1970).

\section{Geochronology and lithostratigraphy}

\section{3.a. Geochronology: previous work}

Dewar (unpub. Ph.D. thesis, Univ. Birmingham, 1965) made the first attempts to construct a lithostratigraphy for Adelaide Island. He defined two major lithological units on the Island: a succession of stratified volcanic and sedimentary rocks and an intrusive suite of granitoids and gabbros. He subdivided the volcanosedimentary succession into three separate mappable units. Dewar (unpub. Ph.D. thesis, Univ. Birmingham, 1965) assigned a probable Late Jurassic age to his Mount Bouvier summit succession based on the 

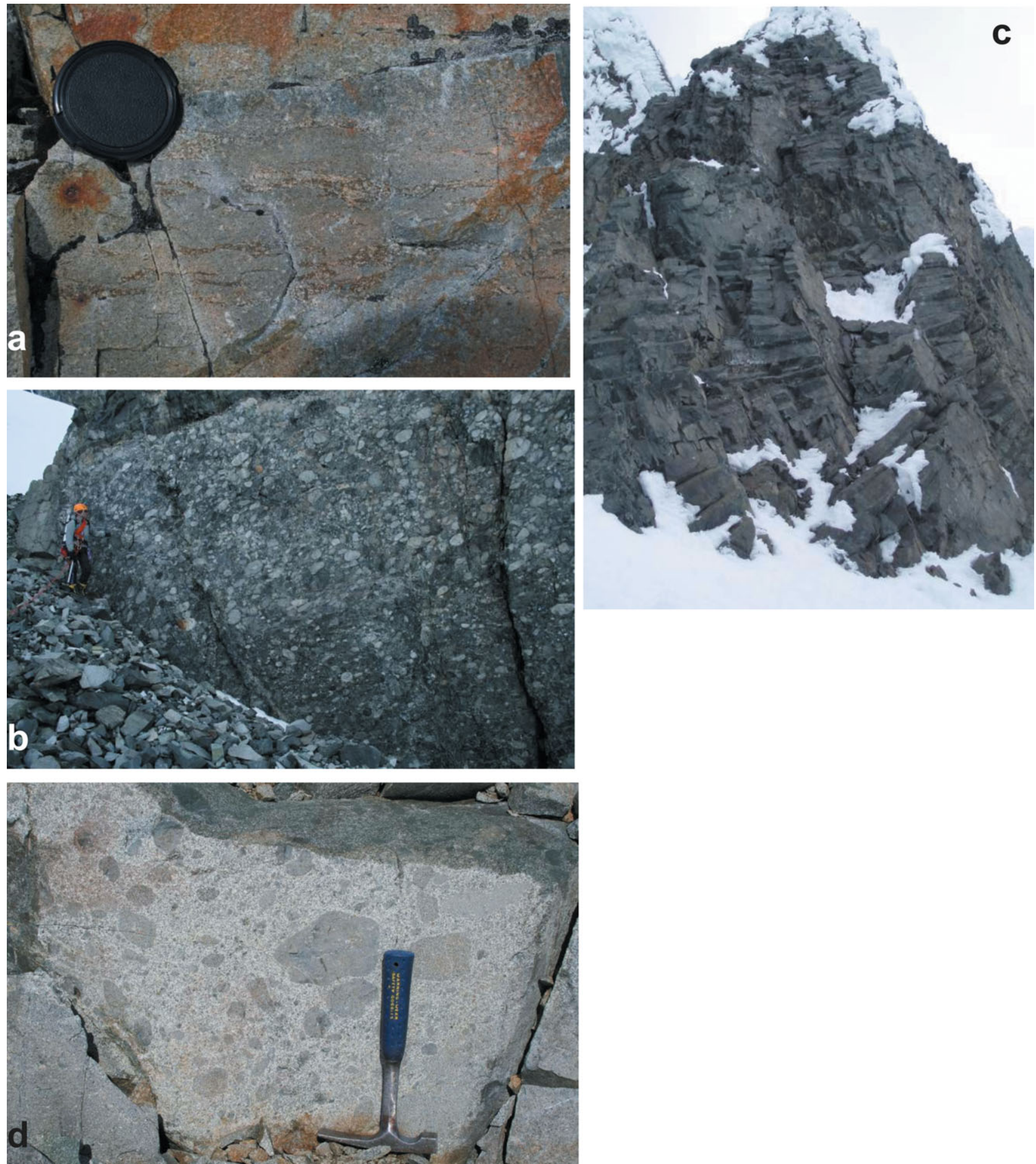

Figure 3. (Colour online) (a) Rhyolitic ignimbrite from the Milestone Bluff Formation, Milestone Bluff. Lens cap is $58 \mathrm{~mm}$ diameter; (b) cobble/boulder conglomerate from Fletcher Bluff, Milestone Bluff Formation; (c) columnar jointing in basaltic andesite lavas, Sighing Peak, Bond Nunatak Formation, $\sim 40 \mathrm{~m}$ height; (d) dioritic 'blebs' in granodiorite host, Rothera Point, Adelaide Island Intrusive Suite.

molluscan fauna from Buchia Buttress, which showed similarities to other southern hemisphere Mesozoic faunas. This age was later verified by Thomson (1972). The successions further south at Milestone Bluff, Fletcher Bluff and Window Buttress also contain a molluscan fauna that was given a probable Late Jurassic age (Thomson \& Griffiths, 1994). However, further south at Cape Alexandra, leaf fossils from hornfelsed mudstones and siltstones were considered to be Cretaceous or even Tertiary in age (Jefferson 1980; Griffiths \& Oglethorpe, 1998).

A limited attempt to date some of the sequences and plutonism on Adelaide Island using $\mathrm{Rb}-\mathrm{Sr}$ dating was made by several workers. Thomson $\&$ Pankhurst (1983) dated a rhyolite from Webb Island, which yielded a $\mathrm{Rb}-\mathrm{Sr}$ whole-rock age of $67 \pm 17 \mathrm{Ma}$. Several plutons have also been dated, yielding Early Tertiary ages: granodiorite-granite plutons from the 


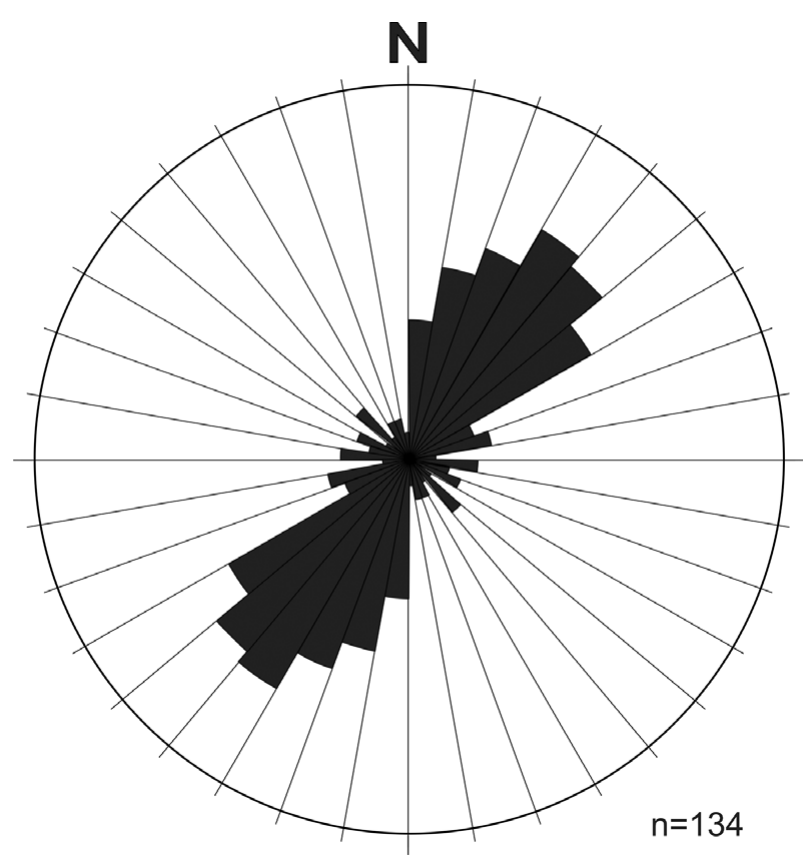

Figure 4. Radial plot of dyke strike direction from Adelaide Island.

Wright Peninsula and Anchorage Island gave ages of $60 \pm 3 \mathrm{Ma}$ and $62 \pm 2 \mathrm{Ma}$, respectively (Pankhurst 1982). A gabbro and aplite from the Faure Islands (25 km south of Adelaide Island) gave an age of $48 \pm 4 \mathrm{Ma}$ (Moyes \& Pankhurst, 1994).

The only other attempt to construct a coherent stratigraphy for Adelaide Island was by Griffiths \& Oglethorpe (1998) who used updated field mapping in combination with new geochronology data. They obtained ${ }^{40} \mathrm{Ar}-{ }^{39} \mathrm{Ar}$ spectra, fission-track dating (zircon, apatite) and $\mathrm{K}-\mathrm{Ar}$ (hornblende) from volcanic rocks, plutonic clasts from conglomerate, as well as dykes from multiple sites across Adelaide Island. The overall picture was somewhat confused with many samples not fulfilling statistically valid criteria, exhibiting Ar loss, excess Ar and possible resetting by later stage plutonism, and other ages not consistent with the molluscan fauna. Their new stratigraphy included six mappable units.

\section{3.b. Geochronology: this study}

The U-Pb (zircon) dating was carried out using a Cameca 1270 (samples J6.347.1, J6.335.1) and a Cameca 1280 (samples J8.403.1, J8.20.1s) ionmicroprobe at the NORDSIM facility, Swedish Museum of Natural History (Stockholm), following the method of Whitehouse \& Kamber (2005). As part of this study, four samples have been dated from separate units across Adelaide Island and all yielded robust, stratigraphically consistent ages (Table 1 ). The combination of new geological mapping, a revised stratigraphy and the new U-Pb (zircon) ages allow some of the ${ }^{40} \mathrm{Ar}-{ }^{39} \mathrm{Ar}$ ages of Griffiths \& Oglethorpe (1998) to be placed in a better context. A coherent
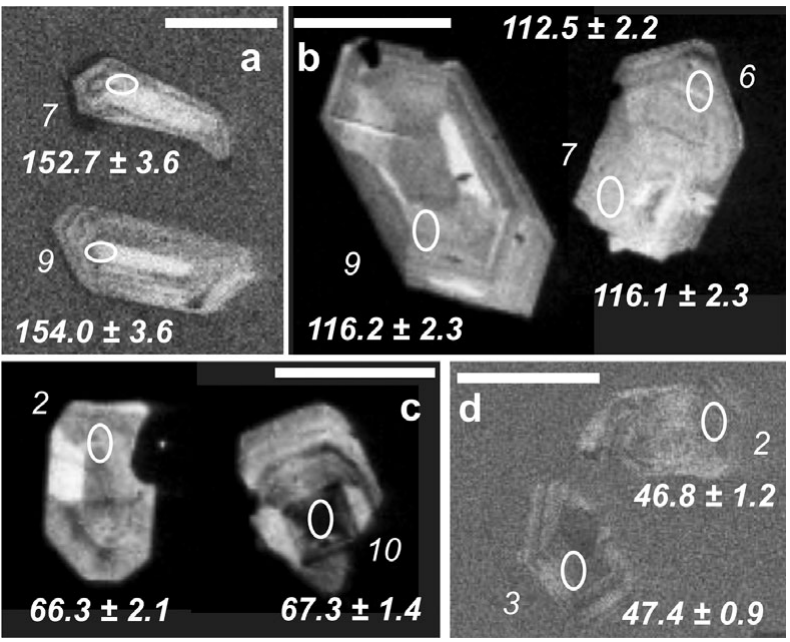

Figure 5. Cathodoluminescence images of analysed zircons. (a) Silicic crystal tuff (J6.347.1) from the Buchia Buttress Formation; (b) rhyolitic ignimbrite (J8.403.1) from the Milestone Bluff Formation; (c) rhyolitic ignimbrite (J8.20.1s) from the Reptile Ridge Formation; (d) tonalite (J6.335.1) from Mount Bouvier. Scale bars are $100 \mu \mathrm{m}$ in length.

litho- and chronostratigraphy also permits improved correlations with the well-dated fossiliferous fore-arc sequences documented from Alexander Island (e.g. Butterworth et al. 1988).

\section{3.c. Buchia Buttress Formation}

A feldspar porphyritic silicic crystal tuff (J6.347.1) from the succession at Buchia Buttress was selected for $\mathrm{U}-\mathrm{Pb}$ analysis. The sample is $\sim 550 \mathrm{~m}$ above the exposed base of the Buchia Buttress Formation and is stratigraphically just above the coarse sandstones where molluscan fossils are most abundant.

Clear, well-faceted, prismatic zircons from the rhyodacitic tuff (J6.347.1) display oscillatory growth zoning under cathodoluminescence (Fig. 5a). Thirteen analyses of zircon yielded ${ }^{206} \mathrm{~Pb}-{ }^{238} \mathrm{U}$ ages with a weighted average of $150.0 \pm 2.5 \mathrm{Ma}$. Excluding two analyses (spot 5: inherited grain, spot 8: high concentration of common $\mathrm{Pb}$ ), the remaining analyses yield a concordia age of $149.5 \pm 1.6 \mathrm{Ma}$ (Fig. 6a), and this age is interpreted to date the eruption of the rhyodacitic crystal tuff. An age of $\sim 150 \mathrm{Ma}$ is in excellent agreement with the molluscan fauna from Buchia Buttress (Thomson, 1972), which was assigned a probable Kimmeridgian-Tithonian age and probably closer to Early Tithonian $(\sim 150 \mathrm{Ma})$.

Griffiths \& Oglethorpe (1998) dated a basaltic lava stratigraphically above $(\sim 250 \mathrm{~m})$ the crystal tuff dated here. The age spectrum showed evidence of Ar loss or alteration, but based on their highest temperature step, they used an age of $76 \mathrm{Ma}$ as the minimum age of eruption (although this unit may form part of the later Bond Nunatak Formation: see later explanation).

The Buchia Buttress Formation is considered to be the lowermost succession exposed on Adelaide Island, and although the tuff sample comes from $\sim 550 \mathrm{~m}$ 
Table 1. U-Pb ion-microprobe zircon data

\begin{tabular}{|c|c|c|c|c|c|c|c|c|c|c|c|c|c|}
\hline $\operatorname{Spot}^{1}$ & $\begin{array}{c}\mathrm{U} \\
(\mathrm{ppm})\end{array}$ & $\begin{array}{c}\text { Th } \\
\text { (ppm) }\end{array}$ & $\begin{array}{c}\mathrm{Pb} \\
(\mathrm{ppm})\end{array}$ & $\mathrm{Th} / \mathrm{U}$ & $\mathrm{f}^{206}(\%)^{2}$ & ${ }^{238} \mathrm{U} /{ }^{206} \mathrm{~Pb}$ & $\pm \sigma(\%)$ & ${ }^{207} \mathrm{~Pb} /{ }^{206} \mathrm{~Pb}$ & $\pm \sigma(\%)$ & $\begin{array}{c}{ }^{206} \mathrm{~Pb} /{ }^{238} \mathrm{U} \\
\text { age (Ma) }\end{array}$ & $\pm \sigma$ & $\begin{array}{c}{ }^{207} \mathrm{~Pb} /{ }^{206} \mathrm{~Pb} \\
\text { age (Ma) }\end{array}$ & $\pm \sigma$ \\
\hline \multicolumn{14}{|c|}{ J6.347.1 Buchia Buttress, volcanic: eruption age $149.5 \pm 1.6 \mathrm{Ma}$} \\
\hline $1^{*}$ & 283 & 283 & 9 & 1.00 & $\{0.77\}$ & 42.795 & 1.12 & 0.05313 & 3.06 & 148.9 & 1.7 & 334.5 & 68.0 \\
\hline $2^{*}$ & 197 & 195 & 6 & 0.99 & $\{0.95\}$ & 43.205 & 1.08 & 0.05106 & 2.81 & 147.5 & 1.6 & 243.4 & 63.4 \\
\hline $3^{*}$ & 504 & 724 & 18 & 1.44 & $\{0.18\}$ & 41.612 & 1.12 & 0.04946 & 2.30 & 153.1 & 1.7 & 169.6 & 53.0 \\
\hline $4^{*}$ & 636 & 713 & 21 & 1.12 & $\{0.31\}$ & 42.281 & 1.10 & 0.04968 & 1.61 & 150.7 & 1.6 & 180.1 & 37.1 \\
\hline $5 \mathrm{i}$ & 156 & 127 & 5 & 0.82 & $\{2.8\}$ & 40.051 & 1.06 & 0.04870 & 3.21 & 159.0 & 1.7 & 133.5 & 73.8 \\
\hline $6^{*}$ & 147 & 123 & 4 & 0.84 & $\{1.39\}$ & 44.088 & 1.06 & 0.04997 & 3.49 & 144.6 & 1.5 & 193.7 & 79.3 \\
\hline $7 *$ & 508 & 692 & 18 & 1.36 & $\{0.36\}$ & 41.713 & 1.17 & 0.04900 & 1.81 & 152.7 & 1.8 & 148.0 & 41.9 \\
\hline 8 & 58 & 53 & 2 & 0.91 & 17.89 & 42.674 & 1.27 & 0.05623 & 5.41 & 149.3 & 1.9 & 461.3 & 115.6 \\
\hline $9^{*}$ & 246 & 290 & 9 & 1.18 & $\{0.85\}$ & 41.352 & 1.18 & 0.04931 & 2.52 & 154.0 & 1.8 & 162.8 & 57.9 \\
\hline $10^{*}$ & 161 & 168 & 5 & 1.04 & $\{1.03\}$ & 42.254 & 1.29 & 0.05048 & 3.14 & 150.8 & 1.9 & 217.0 & 71.1 \\
\hline $11^{*}$ & 232 & 224 & 7 & 0.97 & $\{0.37\}$ & 43.895 & 1.22 & 0.05030 & 3.41 & 144.7 & 1.7 & 145.9 & 2.2 \\
\hline $12^{*}$ & 561 & 831 & 20 & 1.48 & $\{0.24\}$ & 42.996 & 1.29 & 0.04899 & 2.21 & 147.9 & 1.9 & 149.0 & 2.3 \\
\hline $13^{*}$ & 120 & 74 & 3 & 0.62 & $\{0.61\}$ & 42.892 & 1.25 & 0.05149 & 5.34 & 147.7 & 1.8 & 149.4 & 2.3 \\
\hline \multicolumn{14}{|c|}{ J8.403.1 Milestone Bluff, volcanic: eruption age $113.9 \pm 1.2 \mathrm{Ma}$} \\
\hline $1^{*}$ & 197 & 110 & 4 & 0.56 & 1.88 & 57.426 & 1.57 & 0.05000 & 5.45 & 111.3 & 1.7 & 195.0 & 122.1 \\
\hline $2^{*}$ & 288 & 152 & 6 & 0.53 & $\{0.14\}$ & 56.472 & 1.04 & 0.05144 & 2.10 & 113.2 & 1.2 & 260.5 & 47.5 \\
\hline $3^{*}$ & 286 & 161 & 6 & 0.56 & $\{0.11\}$ & 56.083 & 1.00 & 0.04956 & 2.60 & 113.9 & 1.1 & 174.3 & 59.7 \\
\hline $4^{*}$ & 172 & 78 & 4 & 0.45 & $\{0.29\}$ & 57.151 & 1.11 & 0.04763 & 2.72 & 111.8 & 1.2 & 81.0 & 63.3 \\
\hline $5^{*}$ & 305 & 132 & 7 & 0.43 & $\{0.07\}$ & 55.638 & 1.06 & 0.05026 & 1.94 & 114.8 & 1.2 & 207.2 & 44.5 \\
\hline $6^{*}$ & 271 & 134 & 6 & 0.49 & $\{0.11\}$ & 56.804 & 0.99 & 0.05025 & 2.07 & 112.5 & 1.1 & 206.6 & 47.3 \\
\hline $7^{*}$ & 193 & 115 & 4 & 0.60 & $\{0.24\}$ & 55.044 & 1.00 & 0.05021 & 2.49 & 116.1 & 1.1 & 204.8 & 56.7 \\
\hline 8 & 205 & 126 & 5 & 0.61 & $\{0.00\}$ & 56.607 & 1.21 & 0.04748 & 2.68 & 112.9 & 1.3 & 73.6 & 62.4 \\
\hline $9^{*}$ & 212 & 94 & 5 & 0.44 & $\{0.14\}$ & 54.998 & 0.99 & 0.05008 & 2.41 & 116.2 & 1.1 & 198.6 & 55.0 \\
\hline $10^{*}$ & 197 & 77 & 4 & 0.39 & 2.74 & 56.365 & 1.01 & 0.04445 & 10.07 & 113.4 & 1.1 & -85.9 & 230.0 \\
\hline \multicolumn{14}{|c|}{ J8.20.1s Reptile Ridge, volcanic: eruption age $67.6 \pm 0.7 \mathrm{Ma}$} \\
\hline 1 & 70 & 41 & 1 & 0.59 & $\{1.12\}$ & 98.857 & 1.22 & 0.04886 & 5.62 & 64.9 & 0.8 & 141.0 & 126.8 \\
\hline $2^{*}$ & 116 & 83 & 1 & 0.71 & $\{1.53\}$ & 95.249 & 1.56 & 0.04551 & 4.41 & 66.3 & 1.1 & -858.7 & 348.2 \\
\hline 3 & 94 & 94 & 1 & 1.00 & 2.48 & 101.050 & 1.07 & 0.03655 & 18.40 & 63.5 & 0.7 & -589.5 & 437.8 \\
\hline $4^{*}$ & 68 & 54 & 1 & 0.80 & $\{0.85\}$ & 96.389 & 1.28 & 0.05011 & 6.22 & 66.5 & 0.8 & 200.1 & 138.4 \\
\hline $5^{*}$ & 202 & 138 & 3 & 0.68 & $\{0.37\}$ & 94.435 & 1.20 & 0.04339 & 3.39 & 67.9 & 0.8 & -145.4 & 82.1 \\
\hline $6^{*}$ & 93 & 56 & 1 & 0.60 & 4.58 & 96.998 & 1.64 & 0.03384 & 23.85 & 66.1 & 1.1 & -803.4 & 571.5 \\
\hline $8^{*}$ & 74 & 43 & 1 & 0.58 & $\{0.00\}$ & 96.156 & 1.38 & 0.04897 & 5.33 & 66.7 & 0.9 & 146.2 & 120.4 \\
\hline $10^{*}$ & 285 & 184 & 4 & 0.65 & $\{0.79\}$ & 94.518 & 1.05 & 0.04789 & 2.71 & 67.3 & 0.7 & 93.8 & 137.9 \\
\hline $11^{*}$ & 860 & 1023 & 13 & 1.19 & $\{0.20\}$ & 92.974 & 0.84 & 0.04622 & 1.96 & 68.8 & 0.6 & 9.0 & 57.4 \\
\hline $12^{*}$ & 774 & 747 & 11 & 0.96 & $\{0.11\}$ & 93.819 & 0.87 & 0.04688 & 2.03 & 68.3 & 0.6 & 43.1 & 47.9 \\
\hline $13^{*}$ & 218 & 199 & 3 & 0.91 & 1.39 & 96.239 & 1.00 & 0.03895 & 9.49 & 66.6 & 0.7 & -420.3 & 231.8 \\
\hline $14^{*}$ & 61 & 36 & 1 & 0.59 & $\{0.00\}$ & 96.809 & 1.24 & 0.04262 & 7.64 & 66.2 & 0.8 & -189.8 & 181.0 \\
\hline \multicolumn{14}{|c|}{ J6.335.1 Adelaide Island tonalite: intrusion age $47.3 \pm 0.4 \mathrm{Ma}$} \\
\hline $1^{*}$ & 1956 & 1986 & 20 & 1.016 & $\{0.20\}$ & 133.413 & 1.01 & 0.04711 & 1.90 & 48.0 & 0.5 & 54.9 & 44.7 \\
\hline $2^{*}$ & 168 & 164 & 2 & 0.975 & $\{1.44\}$ & 137.319 & 1.36 & 0.04537 & 6.27 & 46.8 & 0.6 & -35.8 & 145.6 \\
\hline $3^{*}$ & 352 & 249 & 3 & 0.708 & $\{0.64\}$ & 134.549 & 0.91 & 0.04270 & 4.68 & 47.4 & 0.4 & -185.0 & 112.9 \\
\hline $4^{*}$ & 154 & 122 & 1 & 0.794 & $\{1.89\}$ & 138.656 & 1.40 & 0.04443 & 6.18 & 45.5 & 0.7 & -87.0 & 145.0 \\
\hline 5 & 164 & 153 & 2 & 0.935 & $\{2.02\}$ & 133.529 & 1.66 & 0.05794 & 8.22 & 47.1 & 0.9 & 527.6 & 170.7 \\
\hline $6^{*}$ & 623 & 553 & 6 & 0.887 & $\{0.56\}$ & 135.853 & 0.86 & 0.04789 & 2.92 & 47.0 & 0.4 & 93.7 & 67.6 \\
\hline $8^{*}$ & 238 & 149 & 2 & 0.627 & $\{0.00\}$ & 138.265 & 1.13 & 0.04844 & 4.80 & 46.5 & 0.5 & 120.6 & 109.3 \\
\hline $9^{*}$ & 225 & 222 & 2 & 0.985 & $\{0.31\}$ & 135.483 & 1.13 & 0.04693 & 5.43 & 47.4 & 0.5 & 45.6 & 125.0 \\
\hline $10^{*}$ & 126 & 90 & 1 & 0.712 & $\{3.91\}$ & 137.405 & 1.52 & 0.04633 & 6.62 & 44.9 & 0.8 & 14.8 & 151.8 \\
\hline
\end{tabular}

${ }^{1}$ Analysis identification. Asterisks show spots included in age calculations; i indicates inherited grain.

${ }^{2}$ Percentage of common ${ }^{206} \mathrm{~Pb}$ estimated from the measured ${ }^{204} \mathrm{~Pb}$. Data is not corrected for common $\mathrm{Pb}$.

Calculations were made using Isoplot 3.1 (Ludwig, 2003) and used the decay constants of Steiger \& Jäger (1977).

Age errors (in text, figure and table) are quoted as $2 \sigma$ except where stated.

above the lowest exposed units, an age of $\sim 150 \mathrm{Ma}$ is considered valid for the formation. The nature of the deposits in the lower part of sequence suggests rapid deposition in a transitional shallow marine apron fan environment.

\section{3.d. Milestone Bluff Formation}

Approximately $80 \mathrm{~m}$ above the exposed base of the Milestone Bluff Formation, a rare silicic crystal-lithic tuff and minor ignimbrite unit overlie a sequence of cobble/boulder conglomerates and coarse sandstones. The entire succession of crystal-lithic tuffs and ignimbrites are $\sim 30 \mathrm{~m}$ in thickness and dip shallowly $\left(<8^{\circ}\right)$ to the northeast. The volcanic rocks are overlain by further cobble/boulder conglomerates. The sample selected for analysis (J8.403.1) was from the ignimbrite unit, which is characterized by typically flattened, porphyritic pumice, with aspect ratios of $\sim 5: 1$ (Fig. 3a).

The ignimbrite is feldspar porphyritic and generally finer grained than the crystal-lithic tuffs with which it is interbedded. The volcanic rocks are mostly subaerial, 

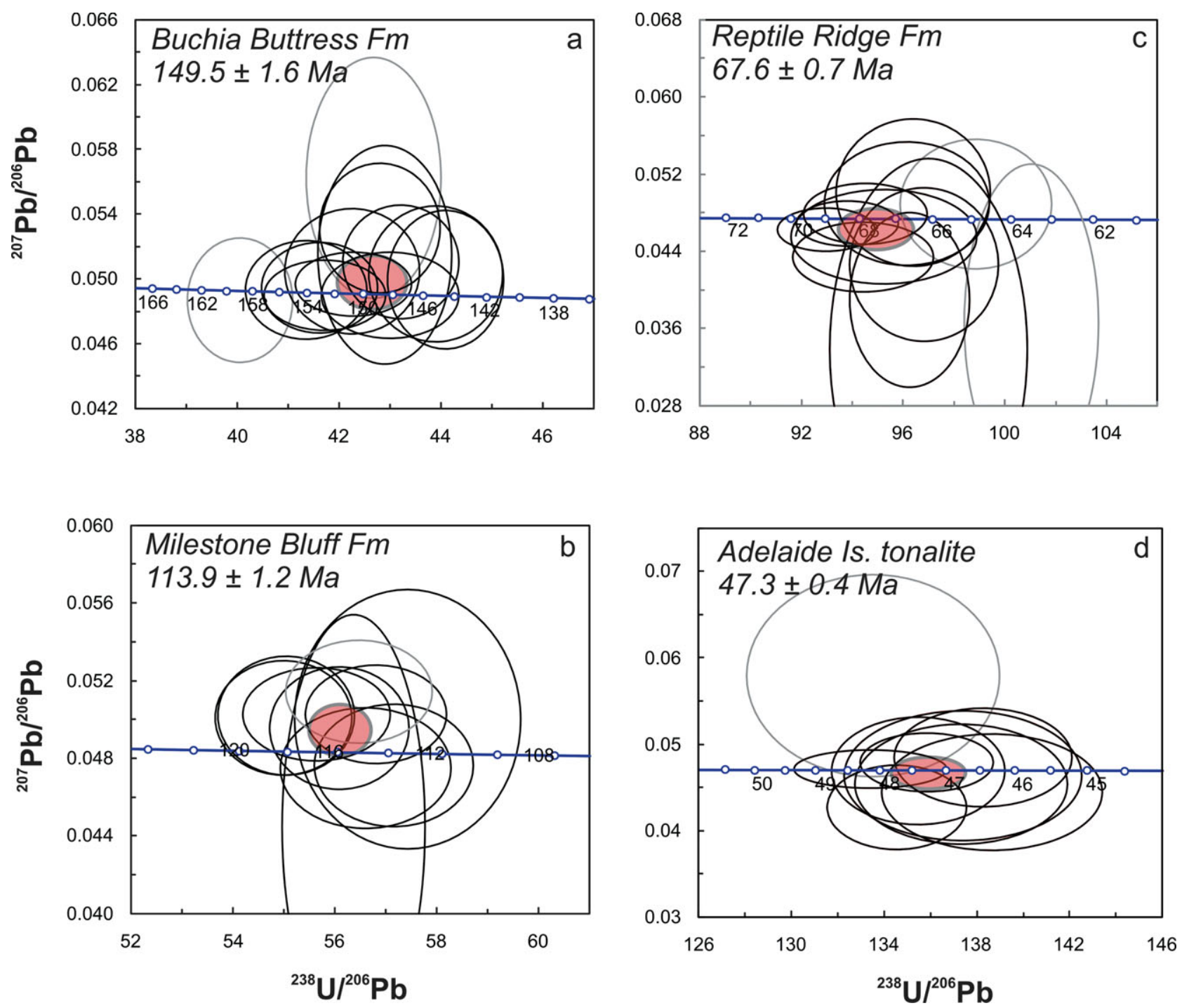

Figure 6. (Colour online) U-Pb concordia diagrams. (a) Silicic crystal tuff (J6.347.1) from the Buchia Buttress Formation; (b) rhyolitic ignimbrite (J8.403.1) from the Milestone Bluff Formation; (c) rhyolitic ignimbrite (J8.20.1s) from the Reptile Ridge Formation; (d) tonalite (J6.335.1) from Mount Bouvier.

but some of the more cherty, laminated crystal tuffs may have been emplaced into water.

Zircons from the rhyodacitic ignimbrite are clear, prismatic and well faceted. Under cathodoluminescence, zircons have patchy and faint oscillatory growth zoning (Fig. 5b), but do not show any evidence for inheritance. Ten analyses on nine grains yield a weighted average of $113.8 \pm 1.1 \mathrm{Ma}$ for the ${ }^{206} \mathrm{~Pb}-{ }^{238} \mathrm{U}$ ages and a concordia age of $113.9 \pm 1.2 \mathrm{Ma}$ (Fig. 6b), which is taken as the preferred age, close to the AptianAlbian boundary (Fig. 7).

Griffiths \& Oglethorpe (1998) also attempted to date a tuff from Milestone Bluff, but the sample suffered Ar loss and gave a poorly defined plateau age of $27.8 \pm 0.6 \mathrm{Ma}$. The Milestone Bluff Formation sequence is also characterized by an abundant belemnite population and rare bivalves, which were considered to be Late Jurassic in age (Thomson \& Griffiths, 1994), but a well-constrained age of $\sim 114 \mathrm{Ma}$ is stratigraphically consistent and indicates a separate phase of sedimentation and volcanism to that exposed in central and eastern parts (Buchia Buttress Formation) and suggests the Late Jurassic age is unreliable.

\section{3.e. Reptile Ridge Formation}

A moderately welded, rhyolitic ignimbrite (J8.20.1s) from the northern section of Reptile Ridge was sampled at a stratigraphic height of $\sim 120 \mathrm{~m}$. The sample is pale grey, fine grained, feldspar porphyritic and is characterized by partially flattened pumice clasts, which are also feldspar porphyritic. The rock is unaltered, but is adjacent to some areas of intense hydrothermal alteration with characteristic mineralization.

The rhyolitic ignimbrite (J8.20.1s) yielded clear, well-faceted, prismatic zircons, with aspect ratios of up to 4:1. They also contain quartz inclusions. Under cathodoluminescence the zircons have typically patchy zoning, but faint oscillatory zoning is evident in most grains (Fig. 5c). Twelve analyses on ten grains have ${ }^{206} \mathrm{~Pb}-{ }^{238} \mathrm{U}$ ages with a weighted average of 


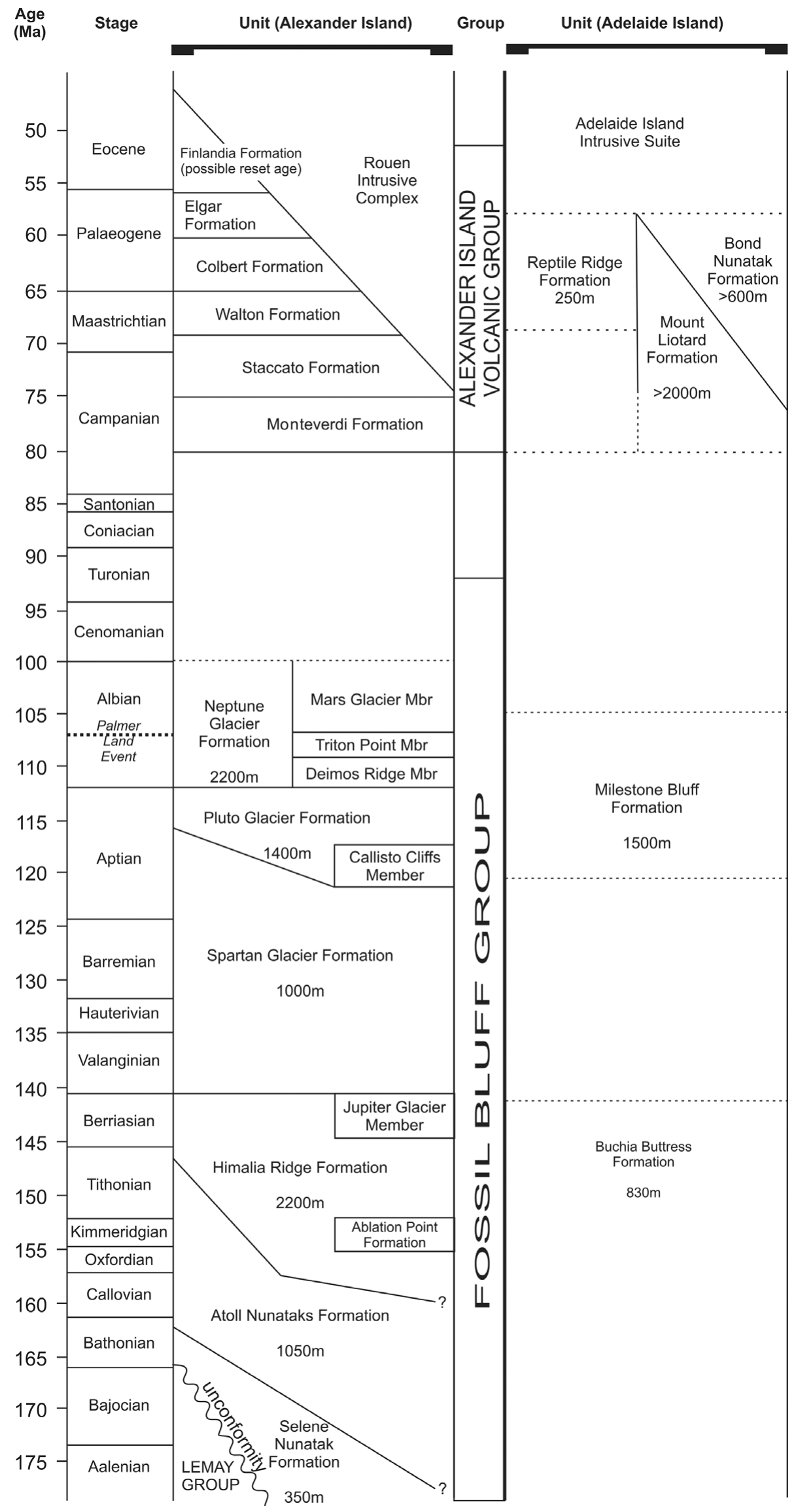

Figure 7. Comparative stratigraphy from Adelaide Island and the Fossil Bluff Group of Alexander Island (from Storey et al. 1996). 
$66.8 \pm 1.0 \mathrm{Ma}$. Excluding two analyses, which are in interpreted to have suffered a small degree of $\mathrm{Pb}$ loss (spots 1,3), a concordia age of $67.6 \pm 0.7 \mathrm{Ma}$ (Fig. 6c) is obtained, and this is the preferred age for Reptile Ridge Formation volcanism.

An age close to the Cretaceous-Tertiary $(\mathrm{K}-\mathrm{T})$ boundary for the Reptile Ridge Formation volcanic rocks of the Wright Peninsula and nearby islands (Fig. 2) is in agreement with the $\mathrm{Rb}-\mathrm{Sr}$ (whole-rock) age (Thomson \& Pankhurst, 1983) of $67 \pm 17$ Ma from Webb Island, albeit with a large degree of uncertainty.

Griffiths \& Oglethorpe (1998) also dated two rhyolitic tuffs from the Reptile Ridge Formation. A sample from Reptile Ridge yielded a poor ${ }^{40} \mathrm{Ar}-{ }^{39} \mathrm{Ar}$ plateau age of $56.2 \pm 0.5 \mathrm{Ma}$ with a spectrum indicating significant Ar loss. A better defined plateau from Piñero Island gave an age of $57.7 \pm 0.5 \mathrm{Ma}$. A granodiorite intruding the Reptile Ridge Formation gave a $\mathrm{Rb}-\mathrm{Sr}$ (whole-rock) age of $60 \pm 3 \mathrm{Ma}$ (Pankhurst, 1982) and a zircon fission-track age of $60.0 \pm 3.7 \mathrm{Ma}$ for an adjacent granodiorite pluton (Griffiths \& Oglethorpe, 1998), both indicating an age of $>60$ Ma for the Reptile Ridge Formation rhyolites.

In summary, an age of $\sim 67 \mathrm{Ma}$ for the Reptile Ridge Formation is considered a reliable date that is geologically consistent. It indicates an entirely separate phase of volcanism on eastern Adelaide Island to the volcanism that punctuates the turbiditic sequences to the west of the Wright Peninsula.

\section{3.f. Bond Nunatak/Mount Liotard formations}

The volcanic rocks of the Bond Nunatak Formation and the Mount Liotard Formation are all basaltic andesiteandesite in composition and are not suitable for $\mathrm{U}-\mathrm{Pb}$ (zircon) dating. But given the improved stratigraphy and chronology from elsewhere on Adelaide Island, it is possible to use existing geochronology with renewed confidence.

Griffiths \& Oglethorpe (1998) dated a basaltic andesite from southern Mount Liotard, which is part of the Mount Liotard Formation. The Ar spectrum was stepped and did not produce a plateau age, although a minimum age of $\sim 63 \mathrm{Ma}$ was interpreted from the maximum step. Another andesite from western Jenny Island (Fig. 2) also forms part of the Mount Liotard Formation and yielded a good plateau age of $49.7 \pm 0.5 \mathrm{Ma}$.

Griffiths \& Oglethorpe (1998) also attempted to date a granitoid clast from one of the conglomerate units at Bond Nunatak, which forms part of the Bond Nunatak Formation. An amphibole separate from the granitoid generated a poor plateau age of 45-50 Ma. There is an indication of significant Ar loss, which was attributed to potential resetting from the nearby Mount Bouvier tonalite intrusion. The highest temperature step gave an age of $59 \mathrm{Ma}$, which was considered the minimum (plutonic) age prior to incorporation in the conglomerate.
The successions that comprise the Bond Nunatak and the Mount Liotard formations are interpreted to be closely related. Basaltic andesite lava flow and breccias dominate both formations, with rare coarse sandstones and conglomerates at Bond Nunatak and Carvajal (Fig. 2).

Many of the ${ }^{40} \mathrm{Ar}-{ }^{39} \mathrm{Ar}$ ages determined by Griffiths \& Oglethorpe (1998) are not considered reliable and have probably been reset by the emplacement of Tertiary-age plutonism. However, a basaltic andesite lava from high up in the Buchia Buttress Formation is more likely to represent part of the Bond Nunatak Formation, overlying the Buchia Buttress Formation. Griffiths \& Oglethorpe (1998) dated this lava sequence and the age spectrum showed evidence of Ar loss or alteration, but based on their highest temperature step, they used an age of $76 \mathrm{Ma}$ as the minimum age of eruption.

A probable age estimate for the Bond Nunatak and Mount Liotard formations is akin to that of the Reptile Ridge Formation, i.e. $\sim 67 \mathrm{Ma}$, but trending towards an older age ( $\sim 75 \mathrm{Ma})$. Unfortunately, no relationship is observed between them, but all three formations are intruded by Tertiary-age granitoid and gabbro plutonic rocks.

\section{3.g. Intrusive rocks of Adelaide Island}

Large parts of Adelaide Island, particularly the central and eastern parts of the Island, are dominated by granitoid and gabbroic plutons (Fig. 2). Previous attempts at dating the age of plutonism have been more successful than the attempts to date the age of volcanism and sedimentation.

Griffiths \& Oglethorpe (1998) used fission-track dating (apatite and zircon) on three granodiorite samples from the Wright Peninsula area (Fig. 2), yielding ages of $44.2 \pm 3.8 \mathrm{Ma}, 52.0 \pm 2.9 \mathrm{Ma}$ and $52.4 \pm 3.5 \mathrm{Ma}$. Two dolerite dykes from the Sheldon Glacier area (Fig. 2) were also dated (K-Ar: hornblende) by Griffiths \& Oglethorpe (1998) and gave average ages of $58 \pm 4 \mathrm{Ma}$ and $48 \pm 6 \mathrm{Ma}$.

As part of this current study, a tonalite (J6.335.1) from near Mount Bouvier (Fig. 2) was dated using $\mathrm{U}-\mathrm{Pb}$ (zircon). The sample was characterized by prismatic zircons with oscillatory zoning, typical of magmatic rocks. The zircons tend to have a non-luminescent outer portion (Fig. 5d). Nine analyses yielded a weighted average ${ }^{206} \mathrm{~Pb}-{ }^{238} \mathrm{U}$ age of $47.0 \pm 0.7 \mathrm{Ma}$, indistinguishable from the preferred concordia age of $47.3 \pm 0.4 \mathrm{Ma}$ (Fig. 6d), which was calculated by omitting one analysis (spot 5) that contained common $\mathrm{Pb}$.

An Eocene age for plutonism on Adelaide Island is consistent with age ranges from previous work (44$58 \mathrm{Ma}$ ) and suggests that plutonism post-dates the main phases of sedimentation and volcanism. At several localities, the acidic-intermediate plutonic rocks are seen in association with the gabbroic rocks of Adelaide 
Island and in all cases, the tonalite-granodiorite rocks are the final intrusive phase.

\section{Correlations along the fore-arc margin}

\section{4.a. The Fossil Bluff Group of Alexander Island}

The Mesozoic fore-arc of the Antarctic Peninsula is well exposed on Alexander Island (Fig. 1) where the stratigraphical relationship between the fore-arc basin and the accretionary complex can be observed (Doubleday, Macdonald \& Nell, 1993). The forearc basin sedimentary rocks on Alexander Island are assigned to the Fossil Bluff Group (Taylor, Thomson \& Willey, 1979).

The entire Fossil Bluff Group has a thickness of $\sim 7 \mathrm{~km}$ of predominantly clastic sedimentary rocks. The lowermost part of the succession (Middle Jurassic; Macdonald et al. 1999) is interpreted as trench-slope apron deposits (Doubleday, Macdonald \& Nell, 1993), whilst the main part of the Group is interpreted as the infill of a fore-arc basin (Butterworth et al. 1988). The sedimentary rocks are mostly marine volcaniclastic deposits with fluvial intervals. Seven formations are recognized within the Group (Selene Nunatak, Atoll Nunataks, Ablation Point, Himalia Ridge, Spartan Glacier, Pluto Glacier and Neptune Glacier formations; Fig. 7), with deposition spanning from Middle Jurassic $(\sim 170 \mathrm{Ma})$ to Albian times ( $\sim 100 \mathrm{Ma})$ (Doubleday, Macdonald \& Nell, 1993; Kelly \& Moncrieff, 1992; Moncrieff \& Kelly, 1993; Nichols \& Cantrill, 2002).

Contemporaneous volcanic rocks are rare in the Fossil Bluff Group, although minor mafic volcanic rocks and silicic tuffs have been identified in the far north and south of the basin (Doubleday \& Storey, 1998). McCarron (1994) documented Late Cretaceous to Early Tertiary volcanic rocks (mostly andesites) in the fore-arc that post-date the main phase of basin-wide sedimentation.

The stratigraphy of the Fossil Bluff Group records two major stages in the development of the fore-arc basin. The two oldest formations (Selene Nunatak and Atoll Nunataks formations; Fig. 7) are exposed on the west side of the basin and record the transition from trench-slope to fore-arc sedimentation (Doubleday et al. 1994). The sediments of these formations were derived from the LeMay Group accretionary complex rather than the main volcanic arc to the east. The later formations are part of the second stage of forearc basin sedimentation and represent a large-scale, shallowing-upward succession from Kimmeridgian age to Albian (Butterworth \& Macdonald, 1991). The Ablation Point Formation (late Kimmeridgian) crops out in the northeast part of the basin and is characterized by sandy turbidites, interpreted as the collapse of a submarine fan complex.

The Himalia Ridge Formation is found throughout the outcrop extent of the Fossil Bluff Group and is interpreted to be a basin-wide feature, with a thickness of $2.2 \mathrm{~km}$, characterized by steep scarp slopes
(Butterworth, 1991). The Himalia Ridge Formation is interpreted as Tithonian in age (Fig. 7), based on bivalve, ammonite and belemnite fauna, located in the lower $1 \mathrm{~km}$ of the succession (Butterworth et al. 1988). The upper $1 \mathrm{~km}$ of the formation largely lacks fossils, with the exception of the upper $50 \mathrm{~m}$, which are regarded as Early Cretaceous in age (Berriasian; Thomson, 1979). The formation is dominated by boulder/cobble conglomerate turbidites and mediumgrained sandstones. The conglomerates typically form beds of 1-4 m thickness and can be structureless or graded. The conglomerate clasts are all arc-derived volcanic and plutonic rocks of acidic composition (Butterworth, 1991). The Himalia Ridge Formation is completely arc-derived and was synchronous with a period of increased arc volcanism (Butterworth, 1991), with the outcrops at the far north of the basin characterized by the occurrence of rare basaltic sills, pillow lavas and rhyolitic sills/lavas, which were considered to be Oxfordian-Kimmeridgian ( $155 \mathrm{Ma}$ ) in age (Macdonald et al. 1999).

The Spartan Glacier Formation is approximately $1 \mathrm{~km}$ in thickness and represents a basin shallowing succession (Butterworth \& Macdonald, 1991) and is characterized by shelf mudstones and thin sandstone units. It contains tectonically induced slide deposits (Storey et al. 1996). The overlying Pluto Glacier Formation is very similar, but has thicker sandstone beds. The formation has a total thickness of approximately $1400 \mathrm{~m}$ and it represents deposition in an inner- to midshelf environment.

\section{4.b. Correlations between Alexander Island and Adelaide Island}

Any correlations between successions on Alexander Island and Adelaide Island are complicated by the significant distance $(150 \mathrm{~km})$ between the two areas, the absence of a basement accretionary complex on Adelaide Island and the paucity of good chronostratigraphic ages for many of the successions. Much of the lithostratigraphy, particularly on Alexander Island and previously on Adelaide Island, is based on molluscan fauna and plant fossil ages, which are in turn based on southern hemisphere correlations. Some molluscan fauna ages have proved robust, but others can be tens of millions of years in disagreement with reliable radiogenic dates. The improved chronoand lithostratigraphy of Adelaide Island has at least permitted tentative correlations to be made with the successions of Alexander Island.

The Buchia Buttress Formation of central Adelaide Island has been reliably dated at $149.5 \pm 1.6 \mathrm{Ma}$ (interbedded crystal tuff), coincident with a Tithonian age suggested by studies of molluscan fauna from the same succession (Thomson, 1972). The boulder/cobble conglomerate and coarse juvenile volcaniclastic sandstones of the Buchia Buttress Formation are interpreted to form a direct correlation or extension of the Himalia Ridge Formation of Alexander Island (Fig. 7), which 
is characterized by coarse-grained conglomeratic rocks and sandstones that form prominent ridge scarps. The rare silicic rocks of the Buchia Buttress Formation are also reported from the Himalia Ridge Formation, along with basaltic pillow lavas, identified from northern Alexander Island (Macdonald et al. 1999) and tentatively dated at $\sim 155 \mathrm{Ma}$. The Buchia Buttress Formation forms the lowermost succession on Adelaide Island, whilst the Himalia Ridge Formation also forms the lowest unit in the main fore-arc succession (Butterworth et al. 1988). Both units are the result of increased volcanic activity in the main arc setting on the Antarctic Peninsula. The primary source of the volcaniclastic and conglomerate material was from the east and southeast of Adelaide and Alexander islands.

A possible correlation between the Milestone Bluff Formation $(113.9 \pm 1.2 \mathrm{Ma})$ and the Aptian-Albian Pluto Glacier Formation is also made. The Pluto Glacier Formation forms some of the youngest rocks of the Fossil Bluff Group and at Succession Cliffs they form the uppermost sequence. Both formations are characterized by alternating units of thickly bedded sandstone and siltstone with occasional pebble/cobble conglomerate channels. Rare green crystal tuffs are reported from the upper part of the Succession Cliffs of Alexander Island (Butterworth et al. 1988), and silicic crystal tuffs and ignimbrites also form occasional horizons in the Milestone Bluff Formation. Ammonites, bivalves and belemnites are present in both formations and have been dated as Aptian-Albian in age at Succession Cliffs (Crame \& Howlett, 1988) and previously thought to be Late Jurassic on Adelaide Island (Thomson \& Griffiths, 1994), an age which is now known to be incorrect given the crystal tuff age reported here.

The three volcanic formations (Mount Liotard, Bond Nunatak, Reptile Ridge) on Adelaide Island have an age close to the $\mathrm{K}-\mathrm{T}$ boundary (Reptile Ridge Formation: $67.6 \pm 0.7 \mathrm{Ma}$ ), which is in good agreement with the fore-arc magmatism described from Alexander Island (McCarron, 1997). The dominantly volcanic sequences from Alexander Island post-date the main episode of fore-arc sedimentation, with the volcanic rocks erupted in the interval 46-80 Ma, with a prominent peak at $\sim 65 \mathrm{Ma}$ (McCarron \& Millar, 1997). Rhyolitic ignimbrites of the Colbert Formation (2.5 km thick) are dated at $64.9 \pm 1.3 \mathrm{Ma}$, $64.6 \pm 1.0 \mathrm{Ma}$ and $63.3 \pm 1.4 \mathrm{Ma}$ and are potentially correlated with the Reptile Ridge Formation rhyolites of Adelaide Island.

The basaltic andesite-dominated Mount Liotard Formation is also correlated with the andesites of the Monteverdi Formation of Alexander Island (Fig. 7), which has been dated at $79.7 \pm 2.5 \mathrm{Ma}(\mathrm{K}-$ Ar: McCarron \& Millar, 1997). The andesite lavas, volcaniclastic rocks and conglomerates of the Bond Nunatak Formation are in turn correlated with the Finlandia Formation of north central Alexander Island (Fig. 7). Ages from the Finlandia Formation are younger ( 45-50 Ma; McCarron \& Millar, 1997) than the Bond Nunatak Formation $(\sim 75 \mathrm{Ma})$, but the Finlandia Formation ages may reflect resetting by nearby Tertiary plutonism, akin to that observed on Adelaide Island. No geochemical data exist for the andesites from the Bond Nunatak or Mount Liotard formations to confirm if they are high-Mg in character.

The pulse of plutonism on Adelaide Island has been dated by several sources (Pankhurst, 1982; Griffiths \& Oglethorpe, 1998; this study) in the interval 44-60 Ma. The plutonic rocks (adamellite, granite, diorite: Rouen Intrusive Complex; Fig. 7) of Alexander Island have also been dated by several sources (Pankhurst, 1982; Storey et al. 1996; McCarron \& Millar, 1997) in the interval 46-75 Ma, suggesting a similar history to that seen on Adelaide Island and a similar compositional range from calc-alkaline granitoids to more mafic compositions. The plutonism on Alexander Island is also associated with late-stage mafic dykes, which cross cut the entire succession.

\section{Tectonic and volcanic implications}

Potential correlations between successions on Adelaide Island and Alexander Island pose interesting issues concerning the position of terrane boundaries on the Antarctic Peninsula as well as the source of the volcaniclastic sediments and also whether the Western Domain (Fig. 1) was exotic (Vaughan \& Storey, 2000).

The volcaniclastic successions on Adelaide Island have been dated in the interval $150-120 \mathrm{Ma}$ and this work has allowed tentative correlations to the Fossil Bluff Group of Alexander Island (Fig. 7). Possible correlations have also been made between the andesiterhyolite sequences of Adelaide Island, which have a total thickness close to $2 \mathrm{~km}$, and the north-south linear belt of fore-arc volcanic rocks on Alexander Island (Alexander Island Volcanic Group; McCarron, 1997). However, such correlations are based on lithological similarities and age relationships, but given the distance between units, the correlations should be treated with caution.

The Late Jurassic-Cretaceous volcano-sedimentary sequences and the Late Cretaceous-Tertiary andesiterhyolite lava successions of Alexander Island and Adelaide Island bracket the Palmer Land tectonic and intrusive event $(\sim 107 \mathrm{Ma}$; Vaughan, Pankhurst \& Fanning, 2002; Leat et al. 2002), which was associated with terrane accretion (Vaughan \& Storey, 2000). The source for the volcaniclastic sediments and conglomerates of the upper parts of the Fossil Bluff Group and the Buchia Buttress and Milestone Bluff formations has to be the main volcanic arc, suggesting coeval volcanic activity from Late Jurassic through to the Albian times. This is consistent with ages determined by Leat et al. (2009) who documented significant volcanic activity in the NW Palmer Land area (Fig. 1) from $\sim 153 \mathrm{Ma}$ to $\sim 107 \mathrm{Ma}$. The NW Palmer Land area is the preferred source region for the fore-arc volcanic and sedimentary rocks and is consistent with the palaeo-flow direction of conglomerate clasts on Adelaide Island (Griffiths 
\& Oglethorpe, 1998). A single granitic conglomerate clast from the Bond Nunatak Formation has yielded an ${ }^{40} \mathrm{Ar}-{ }^{39} \mathrm{Ar}$ whole-rock age of $138.1 \pm 1.9 \mathrm{Ma}$ (Griffiths \& Oglethorpe, 1998), consistent with plutonic ages from NW Palmer Land (Leat et al. 2009). Also, no plutonic rocks of Mesozoic age have been identified either on Adelaide Island or the adjacent coast of Graham Land (Thomson \& Pankhurst, 1993; Griffiths \& Oglethorpe, 1998; this study).

The Late Cretaceous-Early Tertiary andesiterhyolite fore-arc volcanic rocks from Alexander Island are distinct from the main Mesozoic arc volcanic rocks of the Antarctic Peninsula, in that they were generated in the fore-arc as a result of ridge subduction (McCarron, 1997). The $>2 \mathrm{~km}$ sequence of andesite lavas on Adelaide Island is similar in many respects to the Alexander Island succession and is distinct from the volcanic sequences identified from western Graham Land and Palmer Land.

The pre- and post-Palmer Land event correlations, combined with the source region of the volcanosedimentary successions, suggest that Alexander Island and Adelaide Island may have formed part of the same fore-arc terrane in Mesozoic reconstructions of the Antarctic Peninsula and also that an exotic origin for Alexander Island and/or Adelaide Island is unlikely given the requirement to be proximal to a significant sediment/volcanic source region, suggested here as western Palmer Land.

Acknowledgements. This study is part of the British Antarctic Survey Polar Science for Planet Earth programme, funded by the Natural Environmental Research Council. Tom Marshall, James Wake and the air operations staff at Rothera Base are thanked for their field support. Kerstin Lindén and Lev Ilyinsky are thanked for their assistance at the NORDSIM facility. This is NORDSIM contribution number 295. This paper benefited from the considered and helpful reviews of David Macdonald, John Smellie and Simon Kelly.

\section{References}

BUTTERWORTH, P. J. 1991. The role of eustasy in the development of a regional shallowing event in a tectonically active basin: Fossil Bluff Group (Jurassic-Cretaceous), Alexander Island, Antarctica. In Sedimentation, Tectonics and Eustasy (ed. D. I. M. Macdonald), pp. 307-29. International Association of Sedimentologists, Special Publication no. 12. Oxford: Blackwell Scientific.

Butterworth, P. J., Crame, J. A., Howlett, P. J. \& MACDONALD, D. I. M. 1988. Lithostratigraphy of Upper Jurassic-Lower Cretaceous strata of eastern Alexander Island, Antarctica. Cretaceous Research 9, 249-64.

ButTerwORTH, P. J. \& MACDONALD, D. I. M. 1991. Basin shallowing from the Mesozoic Fossil Bluff Group of Alexander Island and its regional tectonic significance. In Geological Evolution of Antarctica (eds M. R. A. Thomson, J. A. Crame \& J. W. Thomson), pp. 449-53. Cambridge: Cambridge University Press.

Crame, J. A. \& Howlett, P. J. 1988. Late Jurassic and Early Cretaceous biostratigraphy of the Fossil Bluff Formation, Alexander Island. British Antarctic Survey Bulletin 78, 1-35.
DEWAR, G. J. 1970. The geology of Adelaide Island. British Antarctic Survey Scientific Reports 57, 66 pp.

Doubleday, P. A., Leat, P. T., Alabaster, T., Nell, P. A. R. \& TRANTER, T. H. 1994. Allochthonous oceanic basalts within the Mesozoic accretionary complex of Alexander Island, Antarctica: remnants of proto-Pacific oceanic crust. Journal of the Geological Society, London 151, 65-78.

Doubleday, P. A., Macdonald, D. I. M. \& Nell, P. A. R. 1993. Sedimentology and structure of the trench-slope to forearc basin transition in the Mesozoic of Alexander Island, Antarctica. Geological Magazine 130, 737-54.

Doubleday, P. A. \& Storey, B. C. 1998. Deformation history of a Mesozoic forearc basin sequence on Alexander Island, Antarctic Peninsula. Journal of South American Earth Sciences 11, 1-21.

Ferraccioli, F., Jones, P. C., VAughan, A. P. M. \& Leat, P. T. 2006. New aerogeophysical view of the Antarctic Peninsula: more pieces, less puzzle. Geophysical Research Letters 33, L05310, doi:10.1029/ 2005 GL024636.

Griffiths, C. J. \& OGlethorpe, R. D. J. 1998. The stratigraphy and geochronology of Adelaide Island. Antarctic Science 10, 462-75.

Haselwimmer, C. E., Riley, T. R. \& LiU, J. G. 2010. Assessing the potential of multispectral remote sensing for lithological mapping on the Antarctic Peninsula: case study from eastern Adelaide Island, Graham Land. Antarctic Science 22, 299-318.

JEFFERSON, T. H. 1980. Angiosperm fossils in supposed Jurassic volcanogenic shales, Antarctica. Nature 285, $157-8$.

Kelly, S. R. A. \& MoncriefF, A. C. M. 1992. Marine molluscan constraints on the age of Cretaceous fossil forests of Alexander Island, Antarctica. Geological Magazine 129, 771-8.

LeAT, P. T., FlowerdeW, M. J., RILEy, T. R., Whitehouse, M. J., Scarrow, J. H. \& Millar, I. L. 2009. Zircon U$\mathrm{Pb}$ dating of Mesozoic volcanic and tectonic events in north-west Palmer Land and south-west Graham Land, Antarctica. Antarctic Science 21, 633-41.

Leat, P. T., Riley, T. R., Wareham, C. D., Millar, I. L., Kelley, S. P. \& STOREY, B. C. 2002. Tectonic setting of primitive magmas in volcanic arcs: an example from the Antarctic Peninsula. Journal of the Geological Society, London 159, 31-44.

LeAT, P. T., ScARrow, J. H. \& Millar, I. L. 1995. On the Antarctic Peninsula batholith. Geological Magazine 132, 399-412.

LUDWIG, K. R. 2003. User manual for Isoplot 3.00, a geochronological toolkit for Microsoft Excel. Berkeley Geochronology Centre Special Publication no. 4, 70 pp.

Macdonald, D. I. M., Leat, P. T., Doubleday, P. A. \& KELLY, S. R. A. 1999. On the origin of fore-arc basins: new evidence of formation by rifting from the Jurassic of Alexander Island, Antarctica. Terra Nova 11, 186-93.

MCCARRON, J. J. 1994. Stratigraphical observations on the Tertiary calc-alkaline volcanic sequences in Alexander Island. Antarctic Science 6, 409-10.

MCCARRON, J. J. 1997. A unifying lithostratigraphy of late Cretaceous-early Tertiary fore-arc volcanic sequences on Alexander Island, Antarctica. Antarctic Science 9, 209-20.

MCCARron, J. J. \& Millar, I. L. 1997. The age and stratigraphy of fore-arc magmatism on Alexander Island, Antarctica. Geological Magazine 134, 507-22.

MonCRIEFF, A. C. M. \& Kelly, S. R. A. 1993. Lithostratigraphy of the uppermost Fossil Bluff Group (Early Cretaceous) of Alexander Island, Antarctica: history 
of an Albian regression. Cretaceous Research 14, 115.

Moyes, A. B. \& PAnkhurst, R. J. 1994. Andean Intrusive Suite. In Geological Map of Adelaide Island to Foyn Coast (eds A. B. Moyes, C. F. H. Willan \& J. W. Thomson), pp. 10-18. BAS GEOMAP Series, sheet 3, 1:250 000, with supplementary text. Cambridge: British Antarctic Survey.

Nichols, G. J. \& CANTRILL, D. J. 2002. Tectonic and climatic controls on a Mesozoic fore-arc basin succession, Alexander Island, Antarctica. Geological Magazine 139, 313-30.

PANKHURST, R. J. 1982. Rb-Sr geochronology of Graham Land, Antarctica. Journal of the Geological Society, London 139, 701-11.

SteIGER, R. H. \& JÄGER, E. 1977. Subcomission on geochronology; convention on the use of decay constants in geo- and cosmochronology. Earth and Planetary Science Letters 36, 359-62.

Storey, B. C., Brown, R. W., Carter, A., Doubleday, P. A., Hurford, A. J., Macdonald, D. I. M. \& Nell, P. A. R. 1996. Fission-track evidence for the thermotectonic evolution of a Mesozoic-Cenozoic fore-arc, Antarctica. Journal of the Geological Society, London 153, 65-82.

TAylor, B. J., Thomson, M. R. A. \& Willey, L. E. 1979. The geology of the Ablation Point-Keystone Cliffs area, Alexander Island. British Antarctic Survey Scientific Reports 82, 65 pp.

Thomson, M. R. A. 1972. New discoveries of fossils in the Upper Jurassic volcanic group of Adelaide
Island. British Antarctic Survey Bulletin 30, 95101.

Thomson, M. R. A. 1979. Upper Jurassic and Lower Cretaceous ammonite faunas of the Ablation Point area, Alexander Island. British Antarctic Survey Scientific Reports 97, $37 \mathrm{pp}$.

Thomson, M. R. A. \& GRIFfiths, C. J. 1994. Palaeontology. In Geological Map of Adelaide Island to Foyn Coast (eds A. B. Moyes, C. F. H. Willan \& J. W. Thomson), pp. 35-8. BAS GEOMAP Series, sheet 3, 1:250 000, with supplementary text. Cambridge: British Antarctic Survey.

Thomson, M. R.A. \& PAnkhurst, R. J. 1983. Age of postGondwanian calc-alkaline volcanism in the Antarctic Peninsula region. In Antarctic Earth Science (eds R. L. Oliver, P. R. James \& J. B. Jago), pp. 328-33. Cambridge: Cambridge University Press.

Vaughan, A. P. M., Pankhurst, R. J. \& Fanning, C. M. 2002. A mid-Cretaceous age for the Palmer Land event: implications for terrane accretion timing and Gondwana palaeolatitudes. Journal of the Geological Society, London 159, 113-16.

Vaughan, A. P. M. \& Storey, B. C. 2000. The eastern Palmer Land shear zone: a new terrane accretion model for the Mesozoic development of the Antarctic Peninsula. Journal of the Geological Society, London 157, 1243-56.

Whitehouse, M. J. \& Kamber, B. 2005. Assigning dates to thin gneissic veins in high-grade metamorphic terranes: a cautionary tale from Akilia, southwest Greenland. Journal of Petrology 46, 291-318. 